С. С. Кольвах, Р. В. Захарченко

Національний університет «Полтавська політехніка імені Юрія Кондратюка», Полтава, Україна

\title{
ВИЗНАЧЕННЯ ОПТИМАЛЬНОЇ ШВИДКОСТІ ОБЕРТАННЯ ЦЕНТРИФУГИ ДЛЯ ЗАБЕЗПЕЧЕННЯ ЯКІСНОГО УЩІЛЬНЕННЯ БЕТОНУ
}

\begin{abstract}
Анотація. У статті розглянуто технологію та машини для виготовлення залізобетонних труб, їх переваги та недоліки. Під центрифугуванням у промисловості будівельних матеріалів розуміють процес ущільнення неоднорідних сумішей у полі відцентрових сил. Ущільнення бетонних сумішей центрифугуванням ефективно використовується при виготовленні напірних і безнапірних труб, опор ліній електропередач, колон та інших конструкцій кільцевого перетину. До основних недоліків формування методом центрифугування необхідно віднести велику потребу в цементі для запобігання розшаровування бетонної суміші при формуванні. Ущільнення слід проводити при такій швидкості обертання, яка забезпечує необхідну початкову міцність виробу, достатню для транспортування його в формах на наступні технологічні пости. На основі аналізу технології виготовлення залізобетонних труб методом центрифугування запропоновано шлях визначення оптимальної швидкості обертання пасової центрифуги за якої забезпечується якісне ущільнення бетону та відсутній розкид суміші із форми.
\end{abstract}

Кл юч ов і слов а : залізобетонна труба, центрифуга, відцентрове формування, технологічна схема, електромеханічний перетворювач.

\section{Ветуп}

Попередньо напружені залізобетонні труби виготовляють методом центрифугування. Технологічний процес їх виготовлення складається 3 низки складних операцій. Значного поширення набули агрегатний та конвеєрний способи виготовлення залізобетонних труб [1]. При агрегатному способі виробництва вироби формують на віброплощадці або на спеціально обладнаних установках-агрегатах, що складаються 3 формувальної машини (зазвичай віброплощадки), машини для розподілу бетонної суміші по формі (бетоноукладчика). Відформовані вироби в формах мостовим краном переміщають в камери теплової обробки бетону для твердіння. Завершальна стадія - видача виробів 3 камери і їх розпалубка на спеціальному посту. Агрегатний спосіб набув широкого поширення і при невеликих капітальних витратах, так як він допускає виконання широкої номенклатури виробів. Конвеєрний спосіб це вдосконалений поточно-агрегатний. У ньому технологічний процес розділений на окремі операції, які виконуються одночасно на окремих робочих постах. Форми з виробами переміщаються від одного поста до іншого спеціальними транспортними пристроями. До основних недоліків формування методом центрифугування необхідно віднести велику потребу в цементі для запобігання розшаровування бетонної суміші при формуванні. Дана стаття присвячена можливості їх усунення.

\section{Основний матеріал}

При відцентровому способі форма із завантаженою в неї бетонної сумішшю обертається 3 певною швидкістю навколо своєї поздовжньої осі [2].

Виникаюча при цьому відцентрова сила розподіляє частки суміші по стінках форми і переміщає їх подалі від осі обертання, при цьому притискає масу до стінок форми, ущільнюючи іiі. В результаті у виробі утворюється внутрішня циліндрична порожнина, що дозволяє здійснювати формування труб і трубчастих конструкцій. Зовнішній обрис поперечного перерізу елементів трубчастої конструкції може бути будь-яким: круглим, багатокутним, квадратним; розміри виробів відцентрового формування можуть бути досить великими як в поперечному перерізі - труби діаметром 2 м і більше, так і по довжині - до 15 м і вище.

Труби відцентрового формування, як і вібраційного, випускаються безнапірними і напірними. Напірні залізобетонні труби повинні забезпечувати водонепроникність трубопроводу при внутрішньому робочому тиску в мережі від 0,6 до 1,0 МПа і більше. Напірні труби випускаються з розтрубом 3 одного кінця, що дозволяє застосовувати ефективну конструкцію непроникних стиків при монтажі трубопроводу. Самі ж труби для забезпечення підвищеної тріщиностійкості при зазначених тисках піддаються попередньому обтисненню 3 доведенням напруги стиснення в бетоні до 10,0 - 15,0 МПа.

Труби і трубчасті конструкції армуються зварними циліндричними каркасами, як правило, 3 ненапруженими поздовжніми стрижнями.

До труб пред'являються високі вимоги щодо точності розмірів в діаметрі, гладкості внутрішньої поверхні і якості бетону.

Бетон в стінках напірних труб має зазвичай марку 500 (В45) [3], його склад призначається при ретельному підборі зернового складу заповнювачів.

Для відцентрового формування застосовуються центрифуги, в яких циліндрична форма 3 бетонною сумішшю обертається із заданою швидкістю. Залежно від способу закріплення форм і приведення їх в обертальний рух розрізняють три типи центрифуг для формування труб і трубчастих конструкцій [4]:

1) осьові центрифуги, в яких форма міцно затискається в торцях між двох бабок 3 планшайбами, центрально насадженими на обертаючи шпинделі;

2) вільно-роликові, в яких форма вільно лягає своїми бандажами на обертові катки (ролики) і притискається до них під дією своєї ваги або притискними верхніми роликами. Передача обертання від 
приводного катка до форми з бетонною сумішшю здійснюється в результаті фрикційного зачеплення;

3) пасові центрифуги, в яких форма вільно підвішена на ременях і приводиться в обертання завдяки силам тертя між пасами і ребордами форми.

Осьова центрифуга має передню нерухому і задню рухливу бабки з затискними планшайбами для закріплення форми в торцях.

Шпинделі передньої і задньої бабок приводяться в обертання головним і розгінним електродвигунами. У серійному виробництві центрифугах для формування труб діаметром від 0,5 до 1,0 м і довжиною до 5 м потужність двигунів становить 115 кВт. Центрифуга має захисний кожух для створення безпечних умов праці. Основними недоліками осьових центрифуг $\epsilon$ велика потужність приводного двигуна та складність завантаження бетонної суміші в форму. Завантаження доводиться здійснювати через центральний отвір в одній 3 планшайб, що вельми ускладнює конструкцію центрифуги.

Вільно-роликова центрифуга по конструкції простіше осьової і вимагає менш потужних двигунів. Центрифуга складається 3 фундаментної рами і двох або трьох паралельних горизонтальних валів 3 насадженими на них по кінцях катками (роликами) в залежності від того, формується одна чи дві труби одночасно; один з валів приводиться в обертання від електродвигуна. Форма своїми бандажами лягає на катки і внаслідок значних сил тертя (при великій вазі форми 3 бетонною сумішшю) приводиться в обертання від катків приводного валу; інші катки, будучи в зачепленні з бандажами форми, також приводяться в обертання. Це дозволяє застосовувати роликові відцентрові верстати, формуючі одночасно дві труби і більш при одному привідному і відповідній кількості ведених валів з катками.

Для забезпечення необхідного зачеплення між бандажами форми і катками центрифуги необхідно, щоб кут $\alpha$, утворений віссю обертання форми і осями обертання двох суміжних ковзанок, був в межах $70 \ldots 90^{\circ}$. Центрифуга складається 3 чотирьох поперечних рам-станин, приводного секційного валу на всю довжину машини, розташованого в нижній частині їі провідних роликів, насаджених на валу в площині поперечних рам і ведених напрямних або притискних роликів, укріплених в підшипниках поперечних рам і розміщуються з боків зверху форми. Поперечні рами, розставлені на відстані до 4 м один від одного, є проміжними опорами для довгих форм, в яких формуються вироби.

Недоліком роликових центрифуг є значний шум і вібрація при роботі. Причиною цього є металеві катки, за якими 3 великою швидкістю котяться бандажі форм, і недостатня збалансованість форм. При недостатній збалансованості форми і великих швидкостях обертання форми з бетонною сумішшю можуть виникати значні відцентрові прискорення, які можуть привести до скидання форм 3 верстата, тому при роботі роликових центрифуг потрібні надійні захисні огородження. Слід зазначити, що для зменшення шуму, що виникає при роботі роликового центрифуги, опорні ролики можуть виконуватися з гумовим покриттям. Крім того, крім відцентрового ущільнення суміші може бути передбачено додаткове ущільнення суміші укочуванням вібровалом, які проходять всередині форми. Такий спосіб ущільнення доцільний тоді, коли до внутрішньої поверхні труби пред'являються підвищені вимоги.

Пасова центрифуга складається з чотирьох поздовжніх валів, з яких один привідний з'єднаний приводом 3 електродвигуном, інші вали ведені; по довжині валів рівномірно розміщені катки 3 кільцевими пазами для пасів. Катки на валах разом з надітими на них пасами утворюють ряд паралельних опор (від чотирьох до шести, в залежності від довжини формованих труб), на які лягає своїми ребордами металева форма. Паси розміщені і натягнуті на катках таким чином, що утворюють V-подібне ложе для форми.

В результаті тертя форми в точках дотику іiі до рухомих ременями вона плавно і безшумно обертається. Кільцеві виточки в ребордах форми створюють своєрідні шляхи кочення форми.

Пасова центрифуга завдяки усуненню вібрації і небезпеки викиду форми з установки дозволяє розвивати швидкість обертання до 1500 об/хв. Потужність двигуна пасової центрифуги для труб діаметром 500 ... 700 мм складає 22 кВт, а для труб діаметром від $1000 \ldots 1200$ мм - 55 кВт.

Основним недоліком пасових центрифуг є відносно невеликий термін служби пасів внаслідок їх витягування та викидання частини бетону із форми через недостатній діапазон регулювання швидкості обертання форми.

Перевагою таких центрифуг є відносно невелика потужність приводного двигуна та, відповідно, менше енергоспоживання у порівнянні 3 іншими типами центрифуг. Усунення викидання частини бетону із форми можна досягти за рахунок використання регульованого електроприводу. Фактори, що впливають на процес центрифугування, наведені на рис. 1. Вхідні фактори або впливу характеризуються тут кількісним складом (C) бетонної суміші: витратою цементу, наповнювачів, води; і якісним (К) іiі складом, активністю цементу, зерновим складом заповнювача, типом добавок. Частоти обертання центрифуги на стадії розподілу $\left(\mathrm{n}_{\text {розп }}\right)$ і ущільнення $\left(\mathrm{n}_{\text {ущіл }}\right)$ відносяться до технологічних параметрів роботи установки $\left(\mathrm{T}_{\Pi}\right)$.

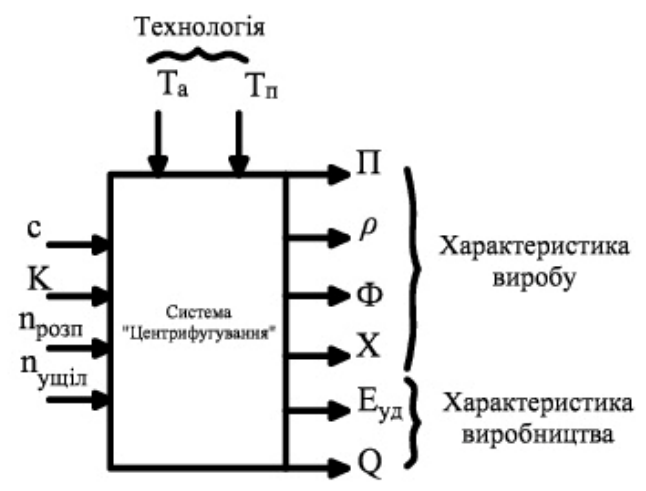

Рис. 1. Фактору впливу на процес центрифугування 
Вихідні чинники: П - пластично-в'язкі характеристики бетону, що визначаються пластичною міцністю $(\mathrm{Pm})$, граничним напруженням зсуву $(\tau 0) \mathrm{i}$ в'язкістю ( $\mu$ ) бетонної суміші; $Ф-$ збереження форми і габаритів вироби, в тому числі товщини труби і якості поверхні; X - збереження проектного розташування арматури; Еуд - питома витрата електроенергії; Q - необхідна продуктивність установки.

Ущільнення суміші слід проводити при такій швидкості обертання, яка забезпечує необхідну початкову міцність виробу, достатню для транспортування його в формах на наступні технологічні пости. Тому швидкодія системи стабілізації швидкості електропривода центрифуги має значний вплив на якість кінцевого продукту. Процес формування виробів центрифугуванням включає дві основні стадії: розподіл бетонної суміші та їі ущільнення. Бетонна суміш розподіляється в формі при мінімальній частоті обертання центрифуги $\mathrm{n}_{\text {кр }}$, при якому виключається можливість розшарування бетону на складові частини (цемент, пісок, щебінь, воду), що мають різну щільність і різну величину відцентрової сили [5]. Крім того, на цій стадії швидкість здатна утримувати частинки бетону в верхньому положенні. Для цього має бути дотримано умову, де відцентрова сила визначається:

$$
F_{L}=m \cdot \omega^{2} \cdot r=(G / g) \cdot(\pi \cdot n / 30)^{2} \cdot r,
$$

де $r$ - радіус обертання центра ваги частинки, м; $g$ прискорення сили тяжіння, м/ $\mathrm{c}^{2} ; n-$ число обертів центрифуги. Частота обертання на стадії розподілу:

$$
n_{\kappa p}^{1}=(30 / \pi) \cdot \sqrt{g / r},
$$

3 урахуванням можливої вібрації, поштовхів і інших відхилень від рівномірного обертання реальна швидкість розподілу збільшується в порівнянні 3 розрахунковою в 1,5 ... 2 рази і дорівнює:

$$
n_{\text {рози }}=n_{\kappa p}^{1} \cdot 1,5 \text {. }
$$

Частота обертання на стадії ущільнення:

$$
n_{\kappa p}^{1.1}=\frac{30}{\pi} \cdot \sqrt{\frac{3 \cdot p \cdot R}{\rho \cdot\left(R^{3}-r^{3}\right)}},
$$

де $p$ - формувальний тиск в центрифугах; $R$ - зовнішній радіус труби; $r$ - внутрішній радіус труби; $\rho$ - щільність бетонної суміші.

Правильність у розрахунках необхідної швидкості обертання центрифуги дозволить точно обрати електромеханічний перетворювач.

\section{Висновки}

У рамках проведених досліджень розглянуто технологічну схему виготовлення залізобетонних труб методом центрифугування та відповідне обладнання, при цьому встановлено: переваги та недоліки кожного типу обладнання; на основі співвідношення переваг та недоліків кожного типу обладнання прийнято найбільш раціональним для подальшого удосконалення пасові центрифуги; знаючи необхідну міцність зовнішньої поверхні труби, можна розрахувати необхідну швидкість обертання центрифуги.

\title{
СПИСОК ЛІТЕРАТУРИ
}

1. Борщ И.М., Прыкин Б.В., Белогуров В.П., Коробкова Е.М. Проектирование заводов сборного железобетона, - Киев: "Будивельник", 1968.-268 с.

2. Родин И.И., Иванов В.Ф., Долгачёва Т.И. Основы проектирования заводов железобетонных изделий. -М.: "Высшая школа", 1966. -312 с.

3. Шейніч Л.О. Сучасні технології бетону / Шейніч Л.О. // Будівництво України. - К.: Основа, 2013. - № 6. - С. 22 - 24.

4. Дахин О.Х., Сиволобова Н.О. Центрифуги, учебное пособие. - Волгоград, РПК «Политехник», 2006. - 61 с.

5. Голованчиков А.Б., Новиков А.Е., Филимонов М.И., Доан М.К. Физическое и математическое моделирование процессов центрифугирования, Монография. - Волгоград: ВГТУ, 2018. - 156 с.

Received (Надійшла) 30.09.2020

Accepted for publication (Прийнята до друку) 04.11.2020

\section{Determination of the optimal rotation speed of the belt centrifuge which provides quality concrete sealing}

\author{
S. Kolvah, R. Zakharchenko
}

Abstract. The article considers the technology and machines for the manufacture of reinforced concrete pipes, their advantages and disadvantages. Prestressed reinforced concrete pipes are made by centrifugation. The technological process of their manufacture consists of a number of complex operations. Aggregate and conveyor methods of manufacturing reinforced concrete pipes have become widespread. In the aggregate method of production, the product is formed on a vibrating platform or on specially equipped units consisting of a molding machine, a machine for distributing the concrete mixture in the form. The aggregate method has become widespread and at low capital costs, as it allows the implementation of a wide range of products. Conveyor method is an advanced flow-aggregate. In it, the technological process is divided into separate operations, which are performed simultaneously on separate workstations. Forms with products are moved from one post to another by special transport devices. The main disadvantages of centrifugal molding include the high need for cement to prevent delamination of the concrete mixture during molding. In the centrifugal method, the mold with the concrete mixture loaded into it rotates at a certain speed around its longitudinal axis. The resulting centrifugal force distributes the particles of the mixture along the walls of the mold and moves them away from the axis of rotation, while pressing the mass to the walls of the mold, compacting it. As a result, an internal cylindrical cavity is formed in the product, which allows the formation of pipes and tubular structures. Centrifuges are used for centrifugal molding, in which a cylindrical mold with a concrete mixture rotates at a given speed. Depending on the method of fixing the forms and bringing them into rotational motion, there are three types of centrifuges for forming pipes and tubular structures: axial centrifuges, free-roller and belt centrifuges. Based on the analysis of the technological scheme of production of reinforced concrete pipes by centrifugation, ways to improve the electromechanical converter are proposed.

Keywords: reinforced concrete pipe, centrifuge, centrifugal molding, technological scheme, electromechanical converter. 